\title{
SOME NOTES ABOUT DECENTRALIZATION PROCESS IMPLICATIONS ON PUBLIC ADMINISTRATION CORRUPTION IN ROMANIA
}

\author{
Tudorel Andrei, Ani Matei, Stelian Stancu, Bogdan Oancea*
}

\begin{abstract}
:
The paper investigates some features of the corruption in the public administration in a country, which is in the process of integrating into the new structures of the European Union. We estimated the parameters of a regression model that analyses factors like political system pressure, administration transparency, and service quality provided by civil servants using data sets for a representative civil servants sample. Using the regression model and ANOVA we came to the conclusion, that the perception of the corruption has significant differences at the level of the four types of public administration institutions analysed in this paper. The main result is that the corruption level in the public administration is negatively influenced by the stability of the remuneration system, by the lack of transparency and by the political system pressure. On the other hand, church, media, and schools have a positive influence on the reduction of the corruption level.
\end{abstract}

Keywords: corruption analysis, econometric models, public administration

JEL Classification: C01, C13, H83

\section{Introduction}

Corruption analysis is an important area of contemporary economic research. The main issues of corruption analysis regard the definition and measurement of the corruption identifying the causes and transmission of the corruption into the system, measurements of the corruption effects on the economic and social environment in a country or a region.

One of the major problems in economic research is the lack of reliable information needed to describe some particular aspects of an economic phenomenon. Regarding corruption analysis, one of the most important issues is the measurement of the corruption level. Thus, choosing the most appropriate indicator for the corruption level measurement and assurance, that this is a universal indicator is a very important problem in this area of research. In the economic literature, there are many indicators used for the

* Academy for Economic Studies, Bucharest (andreitudorel@yahoo.com); National School of Political Studies and Public Administration, Bucharest (amatei@snapa.ro); Academy for Economic Studies, Bucharest (stelian_stancu@yahoo.com); Artifex University, Bucharest

(oanceab@ie.ase.ro). 
corruption level measurement. One of the first indices used for the corruption level was published in the International Country Risk Guide (ICRG). Many companies consult data published by ICRG to make decisions regarding investments localization and business development in certain economic regions. The second index used to measure the corruption level is Corruption Perception Index (CPI) published by the Transparency International (TI) every year. The third index, Corruption Control (CC), was proposed by Kaufmann, Kraay and Mastruzzi (2003) and uses other strategies than the ones of the Transparency International for aggregation of indices that can measure some corruption aspects. We have mentioned that different institutions use other corruption indices, too.

Another important area in corruption phenomenon analysis is the one of identifying the causes, which brings corruption in a system. Economic literature mentions four categories of factors that are directly influencing the corruption.

Political and juridical factors have an important contribution to the process of maintaining the corruption in a system. In the economic literature, one can found a series of studies, that quantify the influence of these factors on the corruption appearance. The main characteristics regarding the political and juridical aspects are political system quality, juridical system features (Leite and Weidmann, 1999), especially legislation and institutions, that fight against corruption, democratic system quality, and electoral system features, administrative system features, administrative decentralization degree, and so on.

Historical factors, culture and tradition have a major contribution in building an attitude against the corruption. A series of studies, like La Porta (1999), Treisman (2000), emphasize the influence of the tradition and historical factors on the level of corruption in a country and appearance and transmissions mechanism's features.

Cultural and social factors have a particular role in emphasizing the corruption features in a specific country. From the most important studies, we would like to point to La Porta (1999), Treisman (2000), Alesina (2003). A series of studies mention the contribution of the religious factors in developing an attitude and behaviour among people regarding the corruption activities.

Economic factors play an important role in corruption propagation. Some of the most important scientific papers mention: the level of economic development (Dreher, 2003; Treisman 2000; Wei, 2001), the public sector size (Tanzi, 1998; Treisman 2000), the level of salaries in the public sector (van Rijckeghem, 1997). Corruption is a problem of the state caused by regulation, and participation of the state in economy. In this context, Otahal (2007) shows "why corruption is a problem of the state rather than of the market".

An important aspect of the research in the area of corruption is the one of the estimation of the corruption effects on the economic, social, and cultural spheres. Some of the most important research directions estimating corruption effects on the economic and social environment are the ones that regard the economic growth in general (Mauro, 1995; Abed and Davoodi, 2000; Krueger, 1974); the growth in some sectors of the national economy (Tanzi, 1998; Shang-Jin Wei, 2001); the decentralization effects on the level and forms of the corruption behaviour (Shah, 2006); the quality of financing in some sectors like the military one (Gupta, 2001), public sector salaries (van Rijckeghem and Weder, 1997); industrial policies in a country (Emerson, 2002; Bhagwati, 1992); investment efficiency (Sarkar, 2001; Mauro 2002). 
In the majority of the above cited publications, the estimation of the corruption impact on some economic and social aspects at the national, sector or regional level the authors made uses the regression models, VAR models, cointegrated sets analysis. In Kaufman (1999), there is a proposal to use simultaneous equations models. In this case, the variables are divided into two classes - endogenous and exogenous, and the Two Stages Least Squares method and the General Method of Moments are applied to estimate the model's parameters. By using these procedures, the exogenous or endogenous character of each variable is taken into account. Regarding this method, we must state, that there is no convenient approach in the economic literature in choosing the instrumental variables list for the process of parameter estimation for the simultaneous equations models used to analyse the corruption in a public system (Bai and Wei, 2000; Kaufmann, Kraay and Zoido-Lobaton, 1999).

\section{Corruption and the Decentralization Process}

Decentralization can take several forms depending of the nature of the functions that are decentralized, the level of the local authorities control over these functions and the type of the institution that takes over the responsibilities.

The objectives of the decentralization process in the developing countries are generally based on the improvements in the efficiency, quality, equity, accessibility and quality of the provided services and of the degree in which these items cover the local needs. In fact, the decentralization is very clearly connected with economic development and democratic governance systems.

The decentralization process aims at improving the performance of a certain service by changing the authority and responsibility between the key actors, improving the informational flow for decision making and performance evaluation, establishing the mechanisms and the modalities of motivating the actors to be responsible in fulfillment of their assignments (Paul L. Hutchinson, 2004).

One of the mechanisms for changes in evaluation of responsibilities is the "responsibility framework" (Brinkerhoff, 2003; Aucoin and Heintzman, 2000). If these changes are applied consistently and coherently, they can reduce the corruption level in the public system.

In the last decade, Romania has made important steps regarding the financial decentralization but the process of implementing this policy has encountered many difficulties due to the lack of a national decentralization strategy. In this process, there are three stages. In the first reform stage (1991-1994), important changes has been initiated regarding the structure and financing of the local authorities that included an introduction of the local tax system. In the second reform stage (1998-2000) new steps to achieve the administrative and financial decentralization have been made. On the basis of the new legislation regarding the local public authority's finances (some amendments to the Law No. 69/1991 and No. 189/1998 on the Public Local Finance) not only the part of the GDP allocated to the local budgets but also the corresponding volume of the local expenditures of the total public expenditures has been increased. Between 1998 and 2001, the ratio of GDP allocated to local budgets has increased from $3.6 \%$ to $6.5 \%$ and the ratio of local expenditures from $14.4 \%$ to $26.6 \%$. During the third reform stage (2001- present), the new laws have been adopted and there have been 
established new rules and regulations for certain functions of the local authorities. We can mention the Law on the Local Public Administration (No. 215/2001) and also other secondary laws regarding public services and municipal economy, local public passengers transport services, public services for community persons record, public municipal services for emergency situations, management of integrated coastal areas, management of urban and rural localities, organization and functioning of public services for water and sewerage, organization and functioning of local public services for administration of public and private domain of local interest.

The corruption and the implementation of an incoherent and inconsistent model of decentralization lead to a strong decrease in the financial resources of each country and to a decrease in the efficiency of these funds. In this context, (i) the developing of an adequate indices system to measure the corruption level and of a corresponding methodology, (ii) establishing of an efficient mechanism to implement the services decentralization, (iii) corruption and decentralization impact on public services evaluation, (iv) evaluation of the transparency of the public funds usage are main priorities for all candidate and member countries of the European Union.

The recommendations of the European Commission and other international organizations (e.g., the World Bank) as the major priorities for Romanian integration into the European Union structures are the reduction of the corruption level and the continuing decentralization process.

Romania benefited from a series of European and World Bank funds to assist the process of decentralization:

- Phare programme 1992 - a 1.5 million ECU project for consolidation of the instruction for the local public administration personnel, local authorities and management abilities development, information publishing and documentation centre development;

- Phare programme 1997 - 5 million ECU allocated in the projects that assisted the local administration to apply the subsidiarity and local autonomy principles;

- Phare programme 2002 - the Decentralization and Local Public Administration Development in Romania project valued at 4.73 million euros helped to sustain the local fiscal decentralization by transferring the coordinating attributions of some activities simultaneously with the creation of some autonomous financial resource at the local level;

- Phare programme 2004 - there are two projects in the course of execution: Decentralization and Deconcentrating Process coordinated by central administration with a budget of 1.4 million euros and Enforcement of the Local Authorities Financial Autonomy by Continuing the Fiscal Decentralization with a budget of 1.2 million euros;

- Phare programme 2005 and 2006 - there are two projects in the course of execution: The Management of the Fund for Local Administration Development and Modernization and The Fund for Local Administration Development and Modernization - Irredeemable Financing Schema for Local Administration;

- PAL programme of the World Bank - a series of activities that consolidated the institutional frame needed for the decentralization process were financed. 


\section{Corruption Phenomenon Analysis Models}

For the purpose of the quantification of the reform process in public administration, a research based on a statistical survey was made in May 2007. During this research, we used a representative sample of the public servants. We used a two-stage sampling technique (Cochran, 1977) and a total number of 971 public servants from local and central administration. In the first stage we included all of the counties in Romania and in the second stage we considered all towns/villages in each county. The error for parameter estimates at the level of referenced population is $1.2 \%$ and the probability for results guarantee is $97 \%$.

We used a statistical questionnaire having several questions grouped to the following areas: internal organization of the public administration institutions, political system pressure on the local and central public administration, decentralization process in administration, public function, gender discrimination in public administration institutions, corruption and its implications on economic and social development at the local and national level. In our questionnaire, we introduced a series of questions regarding personal aspects, like the gender of the person, age, educational level, the type of the institution where he/she works. In the following, we present the most important primary and aggregated variables based on the questions in this questionnaire.

An important variable used to analyse the features of the decentralization process is based on 10 primary variables, that measures the public administration capacity to manage the public goods and public funds at the local level, to assure the public health services, the public social security services, the public educational services, the public cultural services, the public order, the public civil protection services, organizational capacity, forecast and economic and social development. This variable is denoted by $X_{8}$ and is defined on a scale with values in the interval $[1,4]$. If the value of variable $X_{8}$ is closed to 4 , the public administration has a great capacity to accomplish its basic functions. For our sample, the average value of this variable was 2.610 and the standard deviation was 0.590 , which shows a relative reduced capacity for the public administration to accomplish its basic functions.

Taking into account the importance of the financing system of the public services to achieve high quality services we define a new variable that describes the decentralization process quality. This variable is computed based on the values of $X_{8}$ and measures the capacity of the current financing system to satisfy the needs of the local and central public administration institutions. A low value of this variable emphasizes a reduced capacity of the current financing system to assure a good activity in the public administration. The value of this variable for our sample is 2.53 (standard deviation 0.620) which highlights a series of major deficiencies of the public administration to achieve its basic functions and a weak adaptation of the financing system to the public administration institution needs. In fact, the reform strategy states, that in the area of decentralization, there were not enough financial resources and the competences and levels of decentralization were not clearly established. In this line, there are some reform activities to back up the enforcement of the local autonomy of the local authorities by: 
- increasing own funds for the local public administration to a ratio above $50 \%$;

- improving the investments financing system at the local level;

- improving the budget management.

The corruption level in administration $C_{5}$ is a variable that measures the level of corruption in the public sector taking into account the opinions of the public administration employees. Its computation is based on the grades for six corruption evaluation criteria. The values of this variable are between 1 (low level of corruption) and 5 (high level of corruption).

The measure of the corruption equals 3.2 which corresponds to a value of 3.6 on Transparency Corruption Index scale $\left([5-3.2] \cdot \frac{10}{2}=3.6\right)$ shows a high level of corruption in public administration in Romania.

Using econometric models we try to identify the most important factors that influence the level of the corruption in public administration in Romania. We also try to find out if there are different levels of corruption in central public administration, local councils, prefectures, and decentralized services.

The variables we have used in our model are described in the following:

1. The dependent variable of the regression model is $C_{5}$;

2. Explanatory variables are grouped by category, as following:

a. Variables that quantify the influence of the factors that have a contribution to the increase of the corruption in the system. In this category we include contests/examination cheating $\left(C_{9}\right.$ with values between 1 for 4,1 means a low level and 4 means a high level of contests/examination cheating) and the political system pressure ( $X_{6}$ with values between 0 and 4, 0 means no pressure, 4 means the highest level of the political pressure in the process of hiring and promoting civil servants).

b. A variable that quantifies the negative influence of the remuneration system on the corruption level $Q_{2}$. The values of this variable are between 0 (no influence at all) and 4 (the influence is negative and very important).

c. Features that quantify the influence of those factors that leads to the reduction of corruption. In this category we include: the quality of the activity of public administration institutions ( $C_{l}$ with values between 1 and 5,1 means a low quality and 5 a high quality of the activity of public administration institutions), transparency in public administration institutions $\left(C_{2}\right.$ with values between 0 and 4 , 0 means unfavourable situation and 4 means the highest level of transparency), satisfaction degree of the employees from public administration institutions $\left(\mathrm{C}_{3}\right.$ with values between 1 and 5, 1 means a low level of satisfaction, 5 means a high level of satisfaction), quality of the work relationship in the public administration institutions $\left(\mathrm{C}_{4}\right.$ with values between 1 and 4,1 means a low quality of the work relationship and 4 means a high quality of the work relationship), the influence of the press, school, church, civil servants and citizens $\left(\mathrm{C}_{7}\right.$ with values between 1 and 4, 1 means a low influence and 4 means a high influence on the corruption reduction), current capacity of the public administration to achieve its basic 
functions $\left(X_{8}\right)$, the capacity of the financing system of the public services $\left(Q_{1}\right.$ with values between 1 and 4,1 means that financing system has many deficiencies, 4 means a high capacity of the financing system), the quality of the reform process in the public administration $\left(C_{10}\right.$ with values between 1 and 5,1 is the favourable situation and 5 means that the reform process does not encourages the modernization of the public administration).

The general regression model is defined as follows:

$$
\begin{gathered}
C_{5}=b_{0}+b_{1} C_{1}+b_{2} C_{2}+b_{3} C_{3}+b_{4} C_{4}+b_{5} Q_{1}+b_{6} X_{6}+b_{7} X_{8} \\
b_{8} C_{7}+b_{9} C_{9}+b_{10} C_{10}+b_{11} Q_{2}+u_{1}
\end{gathered}
$$

where $u_{1}$ is $I I D\left(0, \sigma^{2}\right)$.

Starting with the general model (M), through successive iterations using techniques described in (Baltagi, 2008) specific regression models was validated for corruption analysis for the following employee categories:

1. For the public administration as a whole (AP) we defined 2 models:

a. $\mathrm{M} 1$ that includes as explanatory variables: $C_{3}, Q_{1}, Q_{2}, X_{6}, C_{7}, X_{8}, C_{9}, C_{10}$;

b. M2 that includes as explanatory variables: $C_{2}, Q_{4}, Q_{2}, X_{6}, C_{7}, X_{8}, C_{9}, C_{10}$;

2. For the central public administration (APC) we defined the following 2 models:

a. $\mathrm{M} 3$ that includes as explanatory variables: $C_{2}, Q_{1}, X_{6}, C_{9}$;

b. M4 that includes as explanatory variables: $Q_{1}, C_{4}, Q_{2}, X_{6}, C_{7}$;

3. For the employees in the local councils $(\mathbf{C J})$ we defined one single model:

a. M5 that includes as explanatory variables: $C_{4}, Q_{2}, C_{9}$;

4. For the employees in the prefectures (P) we defined M6, M7, and M8 models:

a. M6 that includes as explanatory variables: $C_{2}, C_{3}, C_{9}$;

b. M7 that includes as explanatory variables: $C_{3}, Q_{2}, C_{9}$;

c. M8 that includes as explanatory variables: $C_{2}, C_{3}, Q_{2}$;

5. For the employees in the decentralized services (SD) we have 2 models:

a. M9 that includes as explanatory variables: $C_{2}, X_{6}, C_{7}, X_{8}, C_{9}$;

b. M10 that includes as explanatory variables: $C_{2}, Q_{2}, C_{7}, C_{9}$.

For the estimate of the parameters, we considered only the records with valid answers to all of the questions used to define the model's variables. We used OLS and the results are shown in Tables 1,2 and 3. In these tables we show the estimations of the model's parameters together with their standard errors shown in parentheses. We also show the Pearson correlation coefficient between $C_{5}$ and each explanatory variable. 
Table 1

Parameters Estimates for Public Administration (AP) and Central Public Administration (APC)

\begin{tabular}{|c|c|c|c|c|c|c|}
\hline & \multicolumn{3}{|c|}{$\mathbf{A P}$} & \multicolumn{3}{|c|}{ APC } \\
\hline & $\begin{array}{c}\text { Correlation } \\
\text { coefficient }\end{array}$ & $\begin{array}{c}\text { Parameters } \\
\text { for M1 } \\
\end{array}$ & $\begin{array}{c}\text { Parameters } \\
\text { for M2 }\end{array}$ & $\begin{array}{c}\text { Correlation } \\
\text { coefficient }\end{array}$ & $\begin{array}{c}\text { Parameters } \\
\text { for M3 }\end{array}$ & $\begin{array}{c}\text { Parameters } \\
\text { for M4 } \\
\end{array}$ \\
\hline Constant & & $\begin{array}{l}3.080^{*} \\
(0.250) \\
\end{array}$ & $\begin{array}{c}3.621^{*} \\
(0.262) \\
\end{array}$ & & $\begin{array}{c}4.273^{*} \\
(0.382) \\
\end{array}$ & $\begin{array}{l}4.485^{*} \\
(0.628) \\
\end{array}$ \\
\hline $\mathrm{C} 2$ & $-0.323 *$ & & $\begin{array}{l}-0.166^{*} \\
(0.034)\end{array}$ & $-0.464^{*}$ & $\begin{array}{l}-0.292 * \\
(0.071)\end{array}$ & \\
\hline $\mathrm{C} 3$ & $-0.222 *$ & $\begin{array}{l}-0.081^{* * *} \\
(0.039)\end{array}$ & & & & \\
\hline Q1 & $-0.183 * *$ & $\begin{array}{l}-0.053^{* * * * *} \\
(0.031)\end{array}$ & & $-0.323 *$ & $\begin{array}{l}-0.266 * * * \\
(0.093)\end{array}$ & $\begin{array}{l}-0.231 * * * \\
(0.104)\end{array}$ \\
\hline $\mathrm{C} 4$ & $-0.185^{*}$ & & $\begin{array}{l}-0.095 * \\
(0.038)\end{array}$ & $-0.272 *$ & & $\begin{array}{l}-0.294 * * * * * \\
(0.137)\end{array}$ \\
\hline Q2 & $-0.193 *$ & $\begin{array}{l}-0.099 * \\
(0.029) \\
\end{array}$ & $\begin{array}{l}-0.097 * \\
(0.028)\end{array}$ & $-0.317 *$ & & $\begin{array}{l}-0.146^{* * *} \\
(0.087)\end{array}$ \\
\hline X6 & $0.232 *$ & $\begin{array}{c}0.095 * \\
(0.025) \\
\end{array}$ & $\begin{array}{c}0.094 * \\
(0.024) \\
\end{array}$ & $0.261^{*}$ & $\begin{array}{l}0.118^{* * *} \\
(0.056) \\
\end{array}$ & $\begin{array}{l}0.123^{* * *} \\
(0.060)\end{array}$ \\
\hline $\mathrm{C} 7$ & 0.277 & $\begin{array}{c}0.136^{*} \\
(0.031) \\
\end{array}$ & $\begin{array}{c}0.133 * \\
(0.030) \\
\end{array}$ & $0.335^{*}$ & & $\begin{array}{l}0.156^{* * * * *} \\
(0.081)\end{array}$ \\
\hline $\mathrm{X8}$ & $-0.195^{*}$ & $\begin{array}{l}-0.107 * * \\
(0.044)\end{array}$ & $\begin{array}{l}-0.094 * * * \\
(0.042)\end{array}$ & & & \\
\hline C9 & $0.257^{*}$ & $\begin{array}{l}0.142 * \\
(0.034)\end{array}$ & $\begin{array}{c}0.111^{*} \\
(0.034)\end{array}$ & $0.325^{*}$ & $\begin{array}{l}0.162 * * * * \\
(0.089)\end{array}$ & \\
\hline $\mathrm{C} 10$ & $0.118^{*}$ & $\begin{array}{l}0.113 * * * \\
(0.053)\end{array}$ & $\begin{array}{c}0.103^{*} \\
(0.052)\end{array}$ & & & \\
\hline $\mathbf{R}^{2}$ & & 0.438 & 0.460 & & 0.581 & 0.528 \\
\hline $\mathbf{F}$ & & 21.210 & 24.721 & & 12.889 & 7.795 \\
\hline $\begin{array}{l}\text { Number } \\
\text { of valid } \\
\text { cases }\end{array}$ & & 744 & 744 & & 105 & 105 \\
\hline
\end{tabular}

Note: * significant difference from zero for a significance level of $1 \%$; ${ }^{* \star} 2 \%$; ${ }^{* \star *} 3 \%$; ${ }^{* * *} 5 \%$; ${ }^{* \star * \star *} 6 \%$ 
Table 2

Parameters Estimates for Local Councils (CJ) and Prefectures (P)

\begin{tabular}{|c|c|c|c|c|c|c|}
\hline & \multicolumn{2}{|c|}{ CJ } & \multicolumn{4}{|c|}{$\mathbf{P}$} \\
\hline & $\begin{array}{c}\text { Correlation } \\
\text { coefficient }\end{array}$ & $\begin{array}{c}\text { Parameters } \\
\text { for M5 }\end{array}$ & $\begin{array}{c}\text { Correlation } \\
\text { coefficient }\end{array}$ & $\begin{array}{l}\text { Parameter } \\
\text { for M6 }\end{array}$ & $\begin{array}{l}\text { Parameter } \\
\text { for } M 7\end{array}$ & $\begin{array}{c}\text { Parameter } \\
\text { for M8 }\end{array}$ \\
\hline Constant & & $3.805^{*}$ & & $3.990^{*}$ & $\begin{array}{l}3.843 * \\
(0.521)\end{array}$ & $\begin{array}{l}4.747^{*} \\
(0.494)\end{array}$ \\
\hline $\mathrm{C} 2$ & & & $-0.295^{*}$ & $\begin{array}{l}-0.189 * * * \\
(0.092)\end{array}$ & & $\begin{array}{l}-0.189 * \\
(0.093)\end{array}$ \\
\hline $\mathrm{C3}$ & & & $-0.258 * * * *$ & $\begin{array}{l}-0.239 * * * * * \\
(0.128)\end{array}$ & $\begin{array}{l}-0.285^{* * *} \\
(0.127)\end{array}$ & $\begin{array}{l}-0.257 * \\
(0.129) \\
\end{array}$ \\
\hline \multicolumn{7}{|l|}{ Q1 } \\
\hline $\mathrm{C} 4$ & $-0.224 * * * *$ & $\begin{array}{l}-0.234 * * * * * \\
(0.127)\end{array}$ & & & & \\
\hline Q2 & $-0.164 * * * * *$ & $\begin{array}{l}-0.135 * * * * * \\
(0.074)\end{array}$ & $-0.227^{*}$ & & $\begin{array}{l}-0.146 * * * * \\
(0.074)\end{array}$ & $\begin{array}{l}-0.131 * \\
(0.075)\end{array}$ \\
\hline \multicolumn{7}{|l|}{ X6 } \\
\hline \multicolumn{7}{|l|}{ C7 } \\
\hline \multicolumn{7}{|l|}{ X8 } \\
\hline C9 & $0.197 * * * *$ & $\begin{array}{l}0.156 * * * * * \\
(0.088)\end{array}$ & $0.269 * * * *$ & $\begin{array}{l}0.206 * * * \\
(0.101)\end{array}$ & $\begin{array}{l}0.223 * * * \\
(0.100)\end{array}$ & \\
\hline \multicolumn{7}{|l|}{$\mathrm{C} 10$} \\
\hline $\mathbf{R}^{2}$ & & 0.224 & & 0.421 & 0.417 & 0.407 \\
\hline $\mathbf{F}$ & & 4.96 & & 5.254 & 5.115 & 4.826 \\
\hline $\begin{array}{l}\text { Number } \\
\text { of valid } \\
\text { cases }\end{array}$ & & 95 & & 76 & 76 & 76 \\
\hline
\end{tabular}

Note: * significant difference from zero for a significance level of $1 \%$; ${ }^{* *} 2 \% ;{ }^{* * *} 3 \%$; ${ }^{* * *} 5 \%$; ${ }^{* * * * *} 6 \%$ 
Table 3

Parameters Estimates for Decentralized Services (SD)

\begin{tabular}{|c|c|c|c|}
\hline & \multicolumn{3}{|c|}{ SD } \\
\hline & $\begin{array}{c}\text { Correlation } \\
\text { coefficient }\end{array}$ & $\begin{array}{c}\text { Parameters } \\
\text { for M9 }\end{array}$ & $\begin{array}{c}\text { Parameters } \\
\text { for M10 }\end{array}$ \\
\hline Constant & & $\begin{array}{r}3.262 * \\
(0.261) \\
\end{array}$ & $\begin{array}{c}3.254^{*} \\
(0.235)\end{array}$ \\
\hline $\mathrm{C} 2$ & $-0.324 *$ & $\begin{array}{l}-0.178 * \\
(0.044)\end{array}$ & $\begin{array}{l}-0.198^{*} \\
(0.045)\end{array}$ \\
\hline \multicolumn{4}{|l|}{$\mathbf{C 3}$} \\
\hline \multicolumn{4}{|l|}{ Q1 } \\
\hline \multicolumn{4}{|l|}{$\mathrm{C4}$} \\
\hline Q2 & $-0.142 *$ & & $\begin{array}{l}-0.069 * * * * * \\
(0.038)\end{array}$ \\
\hline X6 & 0.249 & $\begin{array}{c}0.126^{*} \\
(0.031)\end{array}$ & \\
\hline $\mathrm{C} 7$ & $0.304 *$ & $\begin{array}{c}0.152 * \\
(0.039)\end{array}$ & $\begin{array}{c}0.162 * \\
(0.039)\end{array}$ \\
\hline X8 & $-0.197 *$ & $\begin{array}{l}-0.114^{*} \\
(0.052)\end{array}$ & \\
\hline C9 & 0.248 & $\begin{array}{c}0.106^{*} \\
(0.043) \\
\end{array}$ & $\begin{array}{c}0.137 * \\
(0.043) \\
\end{array}$ \\
\hline \multicolumn{4}{|l|}{$\mathrm{C} 10$} \\
\hline $\mathbf{R}^{2}$ & & 0.451 & 0.413 \\
\hline $\mathbf{F}$ & & 23.510 & 23.723 \\
\hline Number of valid cases & & 465 & 465 \\
\hline
\end{tabular}

Note: ${ }^{*}$ significant difference from zero for a significance level of $1 \% ;{ }^{* *} 2 \% ;{ }^{* * *} 3 \% ;{ }^{* * * *} 5 \% ;{ }^{* * * * *} 6 \%$

The perception of the corruption has significant differences at the level of the four types of public administration institutions. This conclusion is drawn based on the ANOVA analysis, for which the F statistics is 4.86 and the significance threshold is $p<0.01$. The level of the corruption for the four types of public administration institutions is:

- 3.36 for the central public administration (APC);

- 2.97 for the local councils (CJ);

- 2.98 for the prefectures $(\mathrm{P})$;

- 3.19 for the decentralized services (SD).

We can see that the highest level of corruption is in the central public administration and the lowest level is in the local councils and prefectures.

The ANOVA results recommended that the regression models be defined both for the public administration overall and for the four types of public administration institutions.

The intensification of the reform process at civil service level leads to the reduction of the level of corruption. The parameters that correspond to the variable are significantly different from zero in M1 and M2 models. Civil service reform is one of the major 
priorities of the reform of public administration in Romania consisting in the improvement of civil service management and of the continuing vocational training of civil servants. The major drawbacks at civil service level are grouped to the following categories: (i) the lack of unitary regulations for the public administration staff; (ii) the lack of a stable and efficient remuneration system for civil servants - a system to be applied over a long period of time; (iii) the management of the civil service-which does not fully ensure the fairness of the recruitment, promotion and evaluation of civil servants; (iv) the training of civil servants; (v) the mobility of civil servants.

The press, school, church, and citizens are other factors that lead to the reduction of the corruption.

\section{Conclusions}

An important factor of the corruption is the lack of transparency in the public administration institutions. In fact, in the reform strategy a major goal in the medium term is public administration image improvement through the increase of the transparency of the administrative activities and some anticorruption measures, firm and visible for the public opinion. Excepting the model for the prefectures employees, the parameter that corresponds to this variable has negative values. This demonstrates that the lack of transparency is an important factor that generates corruption in the public administration.

Another important factor for the reduction of corruption is the introduction of a stable remuneration system that will motivate the employees for a long period. Actually, from the three dimensions of the satisfaction degree of the public servant, salary, respect at the work place and work environment, the first one records the lowest level. The average level of this variable is only 2.30 while the other two variables have average values of 3.59 and 3.43 . As the results of the parameter estimation show, the remuneration system does not motivate and stimulate employees to have a positive attitude in the fight against the corruption. For the particular cases of local councils and decentralized services, this factor has neither a positive role nor a negative one.

The negative values that correspond to the parameters for demonstrate the inadvertence of the current remuneration system. Even so, with the assistance of the World Bank there was a study regarding different remuneration systems, however, Romania has not adopted any of them. Thus, the remuneration system is still inefficient in the corruption control.

Our results show the existence of different factors that generate corruption in central public administration, prefectures, local councils, and decentralized services. In these institutions, where there are common factors that have an influence on corruption, they have the same influence - the sign of the parameters from the regression model is the same.

\section{References}

Abed, G., Davoodi, H. (2000), "Corruption, Structural Reforms and Economic Performance in the Transition Economies." IMF Working Paper No. 00/132.

Rose-Ackerman, S. (1975), "The Economics of Corruption." Journal of Public Economics, 5617, June 1975.

Alesina, A. (2003), "Fractionalization." Journal of Economic Growth, 8(2), pp. 155-94.

Andrei, T., Teodorescu, D. (2004), "The Link between Corruption, Development, and the Financing of Defence Systems: Case Study for NATO Ascension Countries." The International Journal of Economic Development, 2004. 
Aucoin, P., Heintzman, R. (2000), “The Dialectics of Accountability for Performance in Public Management Reform." International Review of Administrative Sciences, March 01, 2000.

Bai, Chong-En, Wei, S-J. (2000), "The Quality of the Bureaucracy and Capital Account Policies" World Bank Working Paper No. 2575, 2000.

Baltagi, B. (2008), Econometrics. Fourth Edition, Berlin: Springer Verlag.

Bardhan, P. (1997), "Corruption and Development: a Review of Issues." Journal of Economic Literature, 35, 1997.

Bhagwati, J. N. (1992), "Directly Unproductive, Profit-Seeking (DUP) Activities." Journal of Political Economy, 90, 1992.

Brinkerhoff, R. O. (2003), The Success Case Method: Find Out Quickly What's Working and What's Not. San Francisco, CA: Berrett-Koehler.

Cochran, W. (1977), Sampling Technique. Third Edition, New York: Wiley.

Dreher, A. (2003), "The Influence of Globalization on Taxes and Social Policy - an Empirical Analysis for OECD Countries," Public Economics 0310002, EconWPA, 2003.

Emerson, M., P. (2002), "Corruption and Industrial Dualism in Less Developed Countries." The Journal of International Trade \& Economic Development, 2002, pp. 63-76.

Gupta, S., Davoodi, H., Tiongson, E. (2000), "Corruption and the Provision of Health Care and Educational Services." IMF Working Paper, No. 00/116, 2000.

Gupta, S., Mello, L. de, Sharan, R. (2001), "Corruption and Military Spending." European Journal of Political Economy, 17, pp. 749-777.

Hutchinson, P. L. (2004), "Monitoring and Evaluation of Decentralization Reforms in Developing Country Health Sectors." Tulane University, "The Partners for Health Reformplus Project", September 2004.

Kaufmann, D., Kraay, A., Zoido-Lobaton, P. (1999), "Governance Matters." World Bank Working Paper, 1999.

Kaufmann, D., Kraay, A., Mastruzzi, M. (2003), “Governance Matters III: Governance Indicators for 1996-2002." World Bank Policy Research Working Paper 3106, 2003.

Krueger, A. (1974), "The Political Economy of Rent-Seeking Society." American Economic Review, 64 (3).

Leite, C., Weidmann, J. (1999), "Does Mother Nature Corrupt? Natural Resources, Corruption, and Economic Growth." Working Paper No. 99/85, IMF, Washington, DC.

Mauro, P. (1995), "Corruption and Growth." Quarterly Journal of Economics, 110, pp. 681-712.

Mauro, P. (2002), "The Persistence of Corruption and Slow Economic Growth." IMF Working Papers 02/213, International Monetary Fund, 2002.

Otahal, T. (2007), "Why Is Corruption a Problem of the State?" Prague Economic Papers, 16 (2), pp. 165-179.

La Porta, R., Lopez-de-Silanes, F., Shleifer, A., Vishny, R. (1999), "The Quality of Government," Journal of Law, Economics and Organization, 15(1), pp. 79-222.

Sarkar, H. (2001), "Impact of Corruption on the Efficiency of Investment: Evidence from a Cross-Country Analysis." Asia-Pacific Development Journal, 8 (2).

Schleifer, A., Vishny, R. (1993), "Corruption." Quarterly Journal of Economics, 59, pp. 599-617.

Shah, A. (2006), "Corruption and Decentralized Public Governance." World Bank Policy Research Working Paper, No. 3824, 2006.

Tanzi, V. (1998), "Corruption Around the World: Causes, Consequences, Scope and Cures." IMF Working Paper Washington DC., 1998.

Treisman, D. (2000), "The Causes of Corruption: a Cross-National Study." Journal of Public Economics, 76.

van Rijckeghem, C., Weder, B. (1997), "Corruption and the Rate of Temptation: Do Low Wages in the Civil Service Cause Corruption?" Working paper No. 97/73, IMF Working Paper, Washington DC., 1997.

Wei, S. (1997), "Why Is Corruption So Much More Taxing than Tax? Arbitrariness Kills." Working Paper No. 6255, National Bureau of Economic Research, Cambridge, Massachusetts, 1997.

Wei, S. (2001), Corruption in Economic Development: Grease or Sand? Economic Survey of Europe, No. 2, UN, 2001.

Whitley, B. E. (1998), "Factors Associated with Cheating among College Students: A Review." Research in Higher Education, 39(3), pp. 235-274. 